\title{
WOMAN STRUGGLE IN CAHAYA CINTA PESANTREN NOVEL BY IRA MADAN
}

\author{
AN ARTICLE \\ Submitted in Partial Fulfillment of the Requirements \\ for the Degree of Sarjana Sastra
}

By:

MELINDA RAHMA LUBIS

Registration Number: 2132220009

ENGLISH AND LITERATURE DEPARTMENT

FACULTY OF LANGUAGES AND ARTS

STATE UNIVERSITY OF MEDAN

2017 
ARTIKEL

WOMAN STRUGGLE IN CAHAYA CINTA PESANTREN NOVEL BY IRA MADAN

Disusun dan Diajukan oleh:

Melinda Rahma Lubis

NIM. 2132220009

Telah diverifikasi dan dinyatakan memenuhi syarat

untuk diunggah pada jurnal online

Medan, Juli 2017

Menyetujui

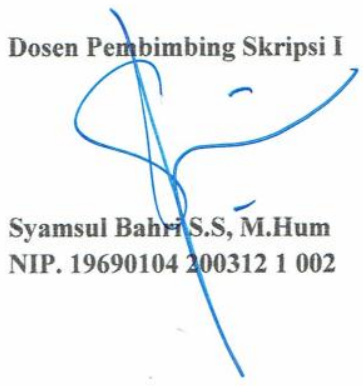

Dosen Pembimbing Skripsi II

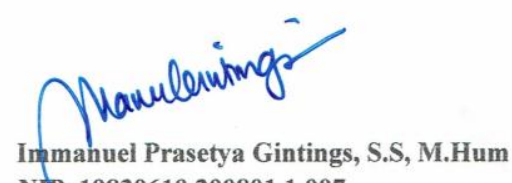

NIP. 198306102008011007

Ketua Prodi Sastra Inggris

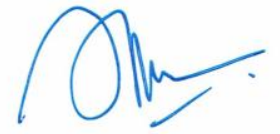

Juli Rachmadani Hasibuan, S.S, M.Hum.

NIP. 198207112008012008 


\title{
WOMAN STRUGGLE IN CAHAYA CINTA PESANTREN NOVEL BY IRA MADAN
}

\author{
*Melinda Rahma Lubis \\ **Syamsul Bahri, S.S, M.Hum. \\ ** Immanuel Prasetya Gintings, S.S, M.Hum.
}

\begin{abstract}
Lubis, Melinda Rahma. 2132220009. Woman Struggle in Cahaya Cinta Pesantren Novel by Ira Madan. A Thesis. English and Literature Department. Faculty of Languages and Arts. State University of Medan. 2017.

The title of this thesis is Woman Struggle in Cahaya Cinta Pesantren Novel by Ira Madan. This study aims to analyzing how is the woman struggle for her ambition of Marshila Silalahi in term of hierarchy of needs that she had faced. The source of the data of the analysis is Cahaya Cinta Pesantren novel and the data are the linguistic features that are formed as sentences by the first woman main character. The writer applies the theories from Maslow (1943) about the hierarchy of needs. Based on its form, Maslow was devided the struggle into 5 stage model, they are (1) Physiological needs, (2) Safety needs, (3) Love and Belonging needs, (4) Esteem needs, (5) Self-actualization. The writer devided the data based on each types of self-actualization by Maslow in Hierarchy of needs. Struggle is related to subconscious mind phychologically, the female character is potrayed to reach her ambition with personal reasons to get something in her struggle. The sources of data of this research are any statements, dialogues and actions that prove or describe the self-actualization of a woman struggle in the novel Cahaya Cinta Pesantren (2014) by Ira Madan. Finally the struggles in each types of selfactualization can be interpreted through Marshila Silalahi sentences of the novel and it is found that hierarchy of needs reflect woman struggle.
\end{abstract}

Keywords : Struggle, woman, self-actualization, novel.

\footnotetext{
*Graduate Status

**Lecturer Status
} 


\section{INTRODUCTION}

\section{Background of the study}

Ambition is the possession of motivation for power.Ambitious persons seek power either for themselves or for others. It's important for human life to have an ambition.Ambition is an eager or strong desire to achieve something such as fame,fortune,or success.To achieve something worth in life, it is necessary to set a high goal.There is a poverb,which says that,a person without ambition has a failure in life.Ambition makes someone becomes apathetic,pessimistic,and easy going.

Literature springs from human inborn love of telling a story,of arranging words in pleasing pattern of expressing in words some special aspect of human experience.There are a number of different branches of literature such as drama,poetry,and prose.Prose itself can be devided into novel,short stories,romance,etc.In this thesis, the main object to be discussed is novel.A novel is a story of book length written in prose.It is about imaginary people and events.Novel also is a part of literature or art.In general,novel reflects the author's experience or true story combined with author's imaginary to make the writing more alive,artistic, and interesting.

The point is that although contemporary works of art have aesthetic properties,their possession of for example, beauty is not taken by their authors or art critics to be what is relevant for their artistic evaluation (Goldie \&

Schellekens 2009) Aesthetic value is not in good repute these days especially among those who,one might think,should be most concerned to boost it that is philosophers,critics and creative artists it might be interesting to inquire into the causes of this disaffection, but it is important to analyze the reasons and to see how far skeptical doubts may be dispelled by a better understanding of what aesthetic value is and why especially in the highly disputed case of literature, its fate is worthy of our concern. 
(Norton 1995) The artistic value of a work can be defined as a composite or an aggregation of its aesthetic,cognitive,historical value.The artistic value of a work of art is thus influenced,but not entirely determined by its aesthetic value.Morality can influence the artistic value of a work in different ways for instance, its moral velue can be part of its cognitive value also influence its aesthetic value.The writer also assume certain controversial theories according to which what is morally good is also thereby aesthetically valuable in a certain sense,perceptually pleasing.In the current debate, it is not always specified whether the moral value of a work of art contributes to its artistic or aesthetic values separetly or to both simultaneously.

Novel is narrative text informing of prose with a long shape that including some figures and fiction event. The intrinsic elements of novel are theme, plot, setting, characterization, point of view, etc (Nurgiyantoro, 2007:10).

The word "ambition"' itself is always closely connected with the achievent of success,and the word "struggle" is related to subconscious mind phychologically.It is an effort to get free to make great effort under difficulties to be content with or against act,and to be confused.I found one of female characters, who is very dominant.She is Marshila Silalahi.The female character is portrayed to reach her ambition with personal reasons to get something in her struggle.In the word,it is clearly portrayed that the female character is having her own of matrealizing her ambition.

It is related to family background that has been succesful.It is a hereditary factor that makes her fight for her ambition.After the death of her father the feeling of dissapointment and sadness has raised the spirit to get success for fulfilling the ambition.

The phenomena above have given me to choose my analysis about woman's struggles for their ambition through Ira Madan's Novel 'Cahaya Cinta Pesantren'. She is my reasons as well as my background in anlyzing the novel in this thesis.

In this proposal i will use the theory of Maslow (1943) stated that people are 
motivated to achieve certain needs and that some needs take precedence over others. Our most basic need is for physical survival, and this will be the first thing that motivates our behaviour. Once that level is fulfilled the next level up is what motivates us, and so on.

1. Biological and Physiological needs - air, food, drink, shelter, warmth, sleep.

2. Safety needs - protection from elements, security, order, law, stability, freedom from fear.

3. Love and belongingness needs - friendship, intimacy, affection and love, from work group, family, friends, romantic relationships.

4. Esteem needs - achievement, mastery, independence, status, dominance, prestige, self-respect, respect from others.

5. Self-Actualization needs - realizing personal potential, self-fulfillment, seeking personal growth and peak experiences.

We can find the woman struggle in the novel Cahaya Cinta Pesantren by Ira Madan (2014), the first woman character is Marshila Silalahi as an object of my analysis. The sentences from the text as the preliminary data can be seen as below:

\section{'Setelah mengikuti banyak ujian dan wawancara,akhirnya aku dinyatakan lulus di sebuah Universitas di Jepang.Fakultas Matematika di Kyushu University’”. ( Cahaya Cinta Pesantren, 2014, pg.140).}

" After attending many exams and interviews, I finally graduated at a university in Japan. Faculty of Mathematics at Kyushu University ". (Light Love Pesantren, 2014, pg.140)

From the example above as preliminary data, we can see how the writer covered the story by using the state of hirarchy of needs. She use "Self Actualization"' in this quotation. In here the first woman character is realizing 
personal potential.

\section{REVIEW OF LITERATURE}

Literature as the media to cultivate the value.Discuss about value and the literature it is closely related. "An author can be recognized by his/her book". This statement means that eventhough the book is not labelled the authors' name but the style will be familiar.It is also happens with the reader, "what he/she read is mirrors of his/her thought. Inclear,literature is the easiest way to cultivate the value.Maybe someone can learn the value from the experience both himself/herself and other,but experiencedoesn't come everyday. Thus, byreading literature people will get the value from the literary work without have to experience.

Based on the topic to be studied, here the researcher chooses novel to be discussed. Novel is one of literary work that which presents some values of character buildings, especially those which are presented by a particular cast of the novel. Infact, reading a novel is able to enrich our understanding in giving interpretation about its content. Furthermore, by reading novel,brings us to know more about various human being aspects and things happen in the reality. 
The Hierarchy of Needs : Levels of the Pyramid

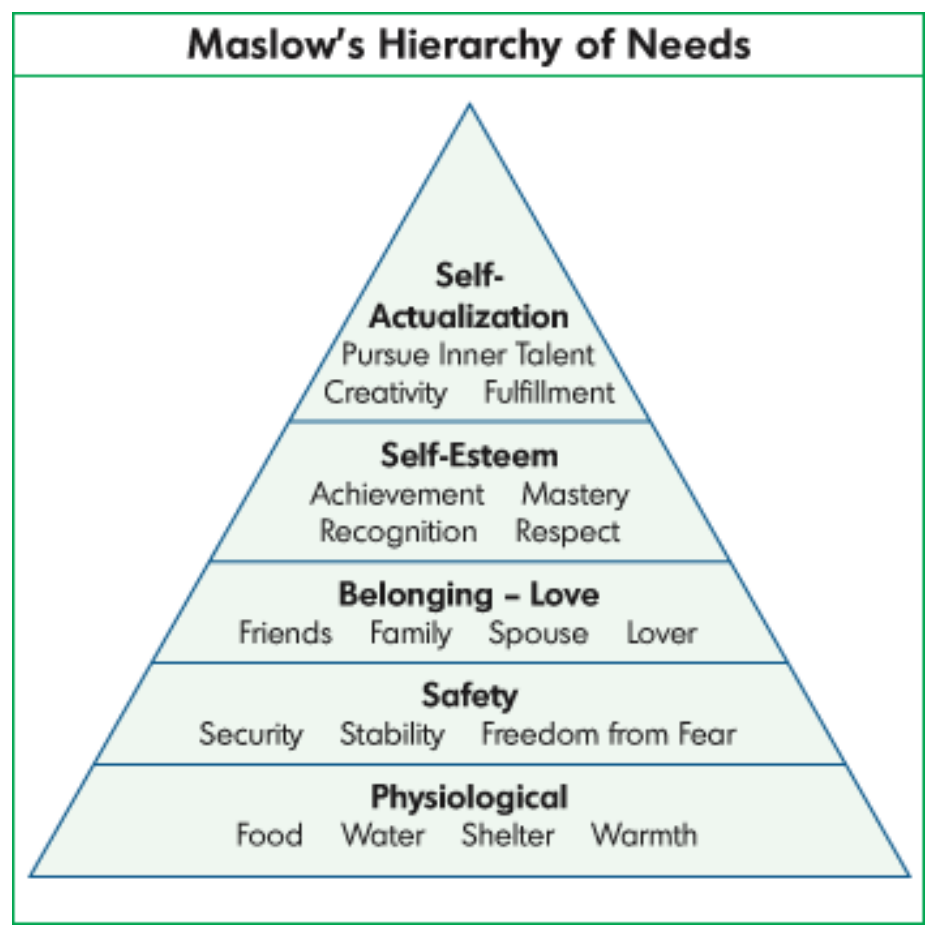

Maslow (1943) stated that people are motivated to achieve certain needs and that some needs take precedence over others. Our most basic need is for physical survival, and this will be the first thing that motivates our behaviour. Once that level is fulfilled the next level up is what motivates us, and so on. At the bottom of the pyramid are the physiological (or basic) needs of a human being: food, water, sleep, and sex. The next level is safety needs: security, order, and stability. These two levels are important to the physical survival of the person. Once individuals have basic nutrition, shelter, and safety, they attempt to accomplish more.

The third level of need is love and belonging, which are psychological needs; when individuals have taken care of themselves physically, they are ready to share themselves with others, such as with family and friends. The fourth level is achieved when individuals feel comfortable with what they have accomplished. This is the esteem level, which includes the need to feel competent and recognized, such as through status and level of success. Then there is the cognitive level, where individuals intellectually stimulate themselves and 
explore. After that is the aesthetic level, which includes the need for harmony, order, and beauty.

At the top of the pyramid, self-actualization occurs when individuals reach a state of harmony and understanding because they have achieved their full potential. Once people have reached the self-actualization stage they focus on themselves and try to build their own image. They may look at this in terms of feelings such as self-confidence, or by accomplishing a set goal. Marshila Silalahi's ambition :

Marshila Silalahi was a tall, slender, attractive young woman, with her eyes were dark brow, and she was friendly, intelligent looking, and self-confidence. Her father was a fisherman. Although she want to continue her study to the popular senior high school in Medan, unfortunatly her parents doesn't agree with her desicion, until her parents getting her to Pesantren Al-amanah to continue her study, even though her survival for her life to reach her ambition to continue the study in Kyushu University in Japan.

\section{'Setelah mengikuti banyak ujian dan wawancara,akhirnya aku dinyatakan lulus di sebuah Universitas di Jepang.Fakultas Matematika di Kyushu University'”. ( Cahaya Cinta Pesantren, 2014, pg.140).}

Marshila Silalahi can getting her purpose, she can realize the potentials in herself and finally successful in her struggles.

I will be use the theory of Maslow offers the following description of selfactualization:

'It refers to the person's desire for self-fulfillment, namely, to the tendency for him to become actualized in what she is potentially." The specific form that these needs will take will of course vary greatly from person to person. In one individual it may take the form of the desire to be an ideal mother, in 
another it may be expressed athletically, and in still another it may be expressed in painting pictures or in inventions' (Maslow, 1943, p. 382-383).

\section{RESEARCH METHODOLOGY}

Methodology

In accomplishing this research, descriptive qualitative method will be applied in this studies. Centralized to Hancock ( 2009:7), qualitative research is concerned with developing explanations of social phenomena. That is to say,it aims at helping us to understand the social world in which we live and why things are the way they are. It is concerned with the social aspects of our world. Qualitative research also tends to focus on how people or groups of people can have different ways of looking at reality. The method will apply by describing the data and analyzing them through some steps that related to the focus of analysis. The reason why the writer chose this method is to explain the problem and its analysis through the theory and show the quality through the finding.

\section{DATA AND DATA ANALYSIS}

This study deals with the struggle of the first woman character in the novel : Cahaya Cinta Pesantren, Marshila Silalahi which is limited to her utterances in the novel. In accordance with the problem and the objectives of the study which have been mentioned in the previous chapter, this study reveals the survival of Marshila Silalahi and the struggle reflection that the character shows in the novel.

The study was conducted using theory the hierarchy of needs by Maslow (1943) in order to find Marshila Silalahi reflection of woman struggle. Maslow (1943) further devides the hierarchy of needs into five levels of the pyramid, physiological, safety, love/belonging, esteem, self-actualization.

The data analysis was divided into two main parts. The first analysis dealt 
with analysis the hierarchy of needs faced by Marshila Silalahi according to Maslow five levels of the pyramid (1943) and the second one dealt with analysing of woman struggle reflection on Marshila Silalahi in term of hierarchy of needs that she had faced.

a. The struggle to motivate herself to continue the study

Motivation is the degree to which feelings of esteem, growth, and competence are expected to result from successful task performance.

One of the reflection of woman struggle is the reflection of fourth stage model in the levels of the pyramid which are called Esteem Needs that Marshila Silalahi had faced.

"I think what a good place this is so as to capture the total hearts of my parents? In fact, to the extent that I can memorize the words of my father and mamak about the title along with the background of the goodness and excellence of the school they call by the name of the pesantren. " (Appendix B,S.[01])

b. The struggle to realize the effort to continue her study

The second thing that reflects the woman struggle is the reflection of third stage model in the levels of the pyramid which are called Love and Belonging Needs that Marshila Silalahi had faced.

" Two days ago I was called by the Research and Development section. They declare that the decision of the deputy board of the pesantren to fly to the State of Sakura has been approved by the boarding school director and can not be contested. " (Appendix B,S.[09])

c. The struggle reason why she realize to continue her study. 
The third thing that reflects the woman struggle is the reflection of five stage model in the levels of the pyramid which are called Self-Actualization that Marshila Silalahi had faced. This is the rare level where people have need of purpose, personal growth and realization of their potentials. People on this level are fully fuctional, acting purely on their own volition and have a on their own volition and have a healthy personality.

After attending many exams and interviews, I finally graduated from a university in Japan. Faculty of Mathematics at Kyushu University. " (Appendix B,S. [13])

\section{CONCLUSIONS AND SUGGESTIONS}

\section{Conclusions}

Based on the research findings found after analyzing the data, it can be concluded that :

1. The five types of Hierarchy Of Needs in "The Cahaya Cinta Pesantren" novel. They are Physiological, safety, love and belongngingness, esteem, self-actualization.

2. Marshila Silalahi has faced every stage. There were three types which were shown by Marshila Silalahi toward the woman struggle. They were esteem needs, love and belonginess needs and self-actualization.

\section{Suggestions}

Having conducted a research about violating maxims, it is useful to consider the following suggestions:

1. The students who are interested in learning woman struggle, should know about the struggle and ambition of the perspective itself in 
order to enrich their knowledge when learn about it. The values of woman struggle are good to be comprehended and from the literary work in the novel, the woman struggle values can be seen from the fulfillment the hierarchy of needs in the level of the pyramid, it is suggested for the students to learn about the struggle deeper and understanding the different aspects in it.

2. The readers should be more struggle and give an effort to reach the ambition with personal reasons to get succes for fulfilling the ambition and finally get the higher levels of needs called selfactualization.

3. The women who live in society in Pesantren to be not live in the silence. Because they have an ability which another regional school doesn't have it. Time to give a big aspiration, inspiration and ideas toward the international level. 


\section{REFERENCES}

Hancock B.,Windridge K ( 2009:7),An Introduction of Qualitative Research. Birmingham:University of Birmingham

Huitt,W.(2007).Maslow's hierarchy of needs.Educational Psychology Interactive.Valdosta,GA: Valdosta State University

Hyland,Nora E (2009), One White Teacher's Struggle for Culturally Relevant Padagogy:The Problem of the Community.The New Educator,5:9-112 Copyright The City College of New York ISSN:1549-9243

Iwuchukwu,O. ( 2008:1),An Intoduction to Literature and Literary Criticism.Lagos:National Open University of Nigeria

Klarer,M (2004:1). An Introduction to Literary Studies.London:Routledge

Maslow,A.(1943).A theory of human motivation.Psychological Review, 50,370396. Retrieved June 2001,from

Maslow,A.(1962) Towards a Psychology of Being.Van Nostrand, New York. Mandrastuty,Rany.(2010) Novel Tarian Bumi Karya Oka Rusmini:Kajian Feminisme.Thesis.Surakata:Universitas Sebelas Maret

Madan,Ira.(2014) Cahaya Cinta Pesantren

Nurgiyantoro,Burhan (2007:10),Teori Pengkajian Fiksi.Yogyakarta:Gadjah Mada University Press

Nurgiyantoro(2007:113),PLOT.Teori Pengkajian Fiksi.Yogyakarta:Gadjah Mada University Press

http://www.edpsycinteractive.org/topics/regsys/maslow.html http://psychclassics.yorku.ca/Maslow/motivation.htm 